${ }^{1}$ Національний університет водного господарства та природокористування, м. Рівне

${ }^{2} B C П$ «Рівненський технічний фаховий коледж» НУВГП, м. Рівне

${ }^{3} B C П$ «Березнівський лісотехнічний фаховий коледж» НУВГП, м. Березне

${ }^{4}$ КНП «Володимирецька центральна районна лікарня», смт Володимирець

\title{
ІНФОРМАЦІЙНО-АНАЛІТИЧНА ТА СОЦІАЛЬНА СКЛАДОВІ БЕЗПЕКИ ФУНКЦІОНУВАННЯ ТЕРИТОРІАЛЬНО-ГОСПОДАРСЬКИХ СИСТЕМ
}

Забезпечити безпечні умови та високу якість життя населення можна тільки за умови встановлення балансу між економічним розвитком і спроможністю відтворення природних ресурсів. Особливо складно це зробити на територіях, які $є$ економічно депресивними та екологічно забрудненими. Аналіз медико-демографічної ситуації у Володимирецькому районі Рівненської області показав, що рівень захворюваності населення за останні 30 років зріс у 3,5 рази. В районі актуальною є проблема захворюваності на хвороби крові, новоутворення, хвороби системи кровообігу, захворюваності на рак щитовидної залози тощо. Насамперед це пояснюється складною радіоекологічною ситуацією в регіоні, що ускладнюеться низкою негативних економічних та соціальних факторів. 3 метою підвищення ефективності надання медичних послуг населенню, запропоновано запровадити інноваційну модель - МІС «ЕМСІМЕД». Вона передбачає використання інформаційних технологій для збору, зберігання, обробки медичних даних та основних показників здоров'я населення, контролю проведення профілактичних оглядів. Крім того, запропоновано включити органічні продукти 3 радіопротекторними властивостями до щоденного раціону хворих. Організувати органічне харчування можна за допомогою кейтерингових послуг (постачання готової їжі для харчування пацієнтів). Вартість органічного комплекту (4-разове харчування) становить від 79 до 89 гривень на день. Реалізація цих заходів забезпечить з часом зниження рівня захворюваності, інвалідності, смертності населення та допоможе подолати несприятливі демографічні тенденції. Водночас, збільшення попиту на органічну продукцію через держзамовлення, 
сприятиме розвитку в регіоні соціально відповідального бізнесу, збереженню та поступовому відновленню родючості ґрунтів, покращенню екологічної ситуації в регіоні в цілому.

Ключові слова: рівень захворюваності населення; інформаційної системи МІС «ЕМСІМЕД»; органічні продукти.

Постановка наукової проблеми та їі значення. Сучасні господарські системи створюються для забезпечення ефективної організації господарської діяльності суб'єктів господарювання. Основними елементами функціонування господарських систем на базі природно-ресурсних комплексів $€$ природні умови, ресурси, структурні соціально-економічні взаємозв'язки, характерні для конкретної території.

Обґрунтуванню механізмів регулювання природокористування загалом та господарських систем зокрема присвячені праці вітчизняних учених П. Борщевського, О. Веклич, В.Голяна, С. Дорогунцова, В. Міщенка, В. Трегобчука, С. Харічкова, М. Хвесика, І. Якушика та інших [1-2]. Однак, на нашу думку, недостатньо приділено уваги розробці заходів та стимулів щодо посилення соціальної та екологічнобезпечної складової, на відміну від тих, котрі гарантують виключно економічну безпеку. Тільки за умови встановлення балансу між економічним розвитком і спроможністю відтворення природних ресурсів на основі їх раціонального використання, можна забезпечити формування безпечних умов життєдіяльності та високої якості життя населення.

Особливо складно забезпечити ефективне функціонування господарських систем на територіях які $€$ економічно депресивними та екологічно забрудненими. Таким $€$ північні райони Рівненської області, що постраждали в наслідок аварії на Чорнобильській АC.

Чорнобильська катастрофа поставила перед постраждалими державами і світовою наукою надзвичайно складні та широкомасштабні проблеми, що стосуються практично усіх сфер суспільного життя, стану і тенденцій навколишнього природного середовища (НПС), сільськогосподарського виробництва, медичної географії, демографії, медичної галузі, продовольчої та екологічної безпеки тощо. Одними із завдань є вивчення механізмів радіаційних ефектів малих доз опромінення на здоров'я населення, а звідси напрацювання превентивних соціо-еколого-економічних інструментів стабілізації й покращання демографічної ситуації 3 населенням у північних областях України.

Важливе значення має визначення чинників, що найбільше впливають на медико-демографічну ситуацію, найбільш значущих 
екологічних чинників (особливо техногенного походження, як таких, що піддаються управлінню). Після аварії на ЧАЕС значне дозове навантаження сформувалось за рахунок радіоактивного йоду. Це пов'язано з тим, що Поліська зона характеризується недостатньою кількістю природного йоду в продуктах харчування та воді, тому щитовидна залоза проживаючих захватила радіоактивний йод у великій кількості. В подальшому основне дозове навантаження становили цезій і стронцій, які поступали в організм з їжею. На даний час основними радіоактивними елементами, що залишаються в грунтах північних районів Рівненської області $є$ цезій-137, стронцій90 та ізотопи плутонію.

Огляд наукових джерел. Вивченням тематики медичної географії, залежності стану НПС та здоров'я населення, соціоеколого-економічного інструментарію мінімізації наслідків антропогенного забруднення на здоров'я населення займались: Антипкін Ю. Г., Березенко В. С., Волосовец А. П., Барановський В. О., Гуцуляк В. М., Гандзюк В. А., Дячук Д.Д., Даценко І. І., Дерик О. 3., Ковальський В. В., Облапенко Г. П., Пащенко В. М., Хлебович І. А., Шевченко В. О., К Кушнірук Ю. С., Волкова Л. А., Кривопустов С. П., Корнус А. О., Кондратюк Н. Ю., К Кольцова Н. І., К Корнацький В. М., Клименко В.І., М Майданник В.Г., Ц Ц Моровський О. М., Чепелевська Л. А., Ященко Ю. Б., Шевчук Л. Т., та ін. [3-12].

Зокрема Кушнірук Ю.С., Волкова Л.А. досліджували медикогеографічні засади дослідження території на прикладі території Рівненської області. Вся інформація була оброблена в інтегральні показники та визначені фактори ризику, які дозволяють обґрунтувати першочерговість проведення природоохоронних заходів для покращення умов проживання населення. На підставі кореляційного аналізу масивів даних встановлено, що між сумарною дозою радіації, накопиченою населенням за 1986-1997рр. та захворюваністю на хвороби ендокринної системи по відповідних районах дорівнює 0,87. Результати дослідження дозволяють говорити про високий кореляційний зв'язок між забрудненням ґрунтів радіонуклідами територій (особливо північних) та захворюваністю населення на хвороби ендокринної системи у відповідних районах. Автори методики рейтингової оцінки території Рівненської області щодо величин медико-екологічного ризику розглядають медико-екологічний ризик як ймовірність виникнення захворювання на конкретній території під впливом комплексу факторів зовнішнього середовища. Він $\epsilon$ одним 3 основних комплексних факторів, які визначають медико-демографічну статистику, рівень загальної смертності і структури смертності, 
рівень загальної захворюваності населення і структуру первинної захворюваності (що корелюється 3 певними факторами геоекосистеми даної території). На підставі даних статистичної звітності була складена просторова оцінка всіх районів Рівненської області [13].

Еколого-географічний аналіз території ґрунтується на комплексному поєднанні принципів екологічної оцінки, географічної характеристики з застосуванням геоінформаційних систем, аналізу медико-демографічних процесів, математичної обробки статистичних матеріалів екологічного та медико-демографічного характеру, що локалізовані на території, яка досліджується.

Постановка наукової проблеми. Аналіз медико-демографічних показників свідчить про зниження тривалості життя населення, народжуваності та природного приросту, підвищення смертності, зростання рівня захворюваності населення країни. Тому дослідження тенденцій захворюваності та поширеності хвороб серед населення $\epsilon$ важливою складовою планування стратегічних напрямів розвитку регіонів у державі, основою для розробки ефективної науково обґрунтованої системи збереження та зміцнення здоров'я населення.

Мета - здійснити аналіз захворюваності та поширеності хвороб за окремими показниками за остані 30 років.

Результати досліджень та їх обговорення. На сьогодні демографічна ситуація у Рівненській області характеризується як незадовільна. Відзначається задовільна народжуваність, висока смертність, невелика середня тривалість життя. На високий коефіцієнт смертності в регіоні впливає значна частка осіб пенсійного віку, захворюваність населення, низький рівень медичного обслуговування, низький рівень життя, відсутність профілактичних оглядів та заходів 3 врахування стану НПС в сільськогосподарському виробництві та способі життєдіяльності.

Таким чином, аналіз стану здоров'я постраждалого населення виявив у динаміці негативні тенденції щодо погіршення стану здоров'я як дорослого, так і дитячого населення, відмінності в рівнях і структурі захворюваності у порівнянні з населенням, яке не підпало під дію радіації, які характерні для раннього і віддаленого періодів упливу наслідків катастрофи на ЧАЕС [14].

Після катастрофи важливою є оцінка стану здоров'я осіб, які знаходилися під впливом різних доз іонізуючого опромінення. Але в останні роки екологічні, соціальні та психологічні проблеми відіграють вирішальну роль у формуванні стану здоров'я 
Серія «Економічні науки»

Випуск 4(92) 2020 p.

постраждалого населення. Через 10 років Чорнобильської катастрофи питома вага хворих різко зросла, наприклад в Житомирській області хворими є уже 69,7\% оглянутих $(76,3 \%$ в Україні). У 2005 році в області хворими є 76,6\% постраждалого населення (в Україні - 85,8\%). Якщо серед дорослих і підлітків у 1987 році хворими було 52,6\% населення, то у 1993 році - вже $72 \%$, а у 2005 році таких хворих стає 81,2\%. Особливістю захворювань є те, що на початку катастрофи, у 1987 році, левову частку у структурі захворюваності займали хвороби ендокринної системи - 62,7\% [15].

У подальшому відбувається перерозподіл структури захворюваності. Так, патологія системи дихання протягом 19881996 рр. займає перше місце - 33,3\% (проти 2,15\%). Наукові дослідження, що були проведені у цей період, показують різке зростання патології органів дихання через аерозольне розповсюдження радіоактивно забрудненого пилу [16]. На другому місці у структурі захворюваності є хвороби кістково-м'язової системи - 22\% (в 1987 році тільки 0,86\%). Це дає підстави припустити, що за 8-10 років після катастрофи елементи розпаду радіонуклідів замістили кальцій у кістковій системі людини [17]. Хвороби нервової системи залишаються на третьому місці - 10,7\%. Зросла питома вага захворювань сечостатевої системи і склала 7,9\% (проти 0,05\% у 1987 та 3,8\% у 1990 рр.). Захворювання системи кровообігу у загальній структурі захворюваності на шостому місці і становлять 6,4\%. Слід відзначити, що у структурі захворюваності відбуваються зміни щодо збільшення питомої ваги патології інших систем організму. Можна припустити, що тенденція до зростання інфекційної захворюваності пов'язана з порушенням імунного статусу популяції [18; 19].

Сучасна структура причин смерті населення України поєднує у собі елементи традиційної і сучасної структури патології: хвороби системи кровообігу, новоутворень, хвороб органів дихання та органів травлення. Такі хвороби $€$ не менш значимими у порівнянні із смертністю від екзогенних причин: нещасні випадки, травми та отруєння тощо. У середньому до $86 \%$ усіх смертних випадків нині в Україні припадає на три основні класи причин смерті: хвороби системи кровообігу, новоутворення і зовнішні причини смерті. Поширеність хвороб системи кровообігу в регіональному аспекті характерна і для північних областей України. При проведенні порівняння відповідних показників у 2008 та 2015 роках встановлено, що найбільше він зріс у Житомирській - на 34,11\% (із 47243,4 на 100 тис. нас. до 71703,6 на 100 тис. нас.), Рівненській на 30,17\% (із 44707,7 на 100 тис. нас. до 64019,2 на 100 тис. нас.) та 
Миколаївській - на 29,32\% (із 54784,9 на 100 тис. нас. до 77510,8 на 100 тис. нас. [20-21].

Головна визначена закономірність - це відповідність формування здоров'я населення у просторово-часовому вимірі екологічним факторам. Роль окремих груп факторів $\epsilon$ не однаковою $\mathrm{i}$ визначає динаміку захворюваності за різними класами хвороб, структуру та динаміку смертності.

Для аналізу потреб у лікуванні, створення системи інформації нами проаналізована інформація щодо медичної статистики за даними Володимирецької районної лікарні. Наприклад, динаміка народжуваності населення Володимирецького району (рис. 1), природний приріст населення (рис. 2) та малюкова смертність (рис. 3)

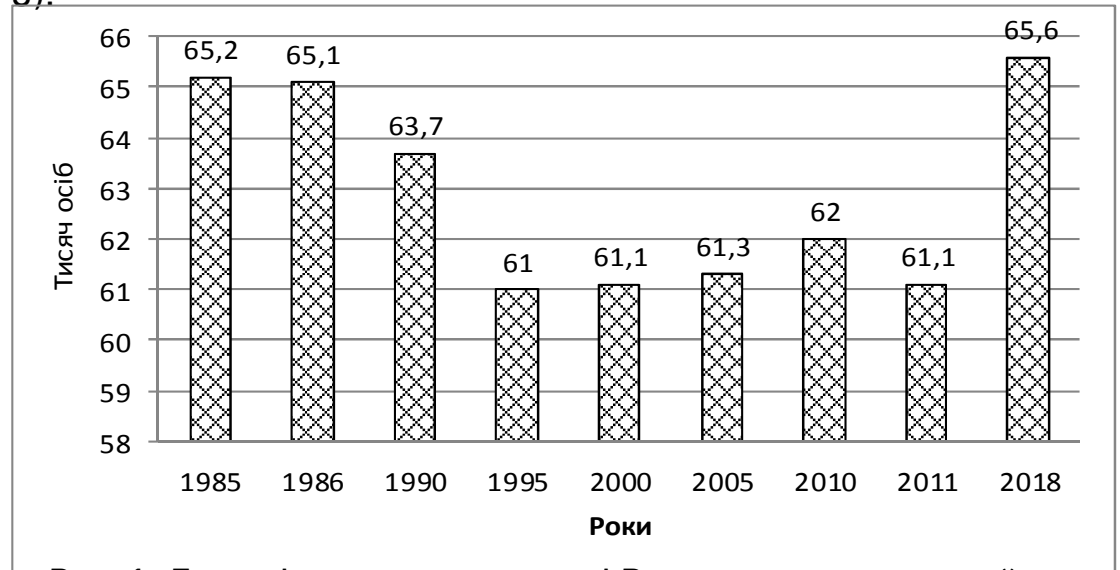

Рис. 1. Динаміка народжуваності Володимирецького району

Динаміку природного приросту населення Володимирецького району на 1000 осіб населення наведено на рис. 2. Аналіз рисунку засвідчує зменшення природного приросту населення.

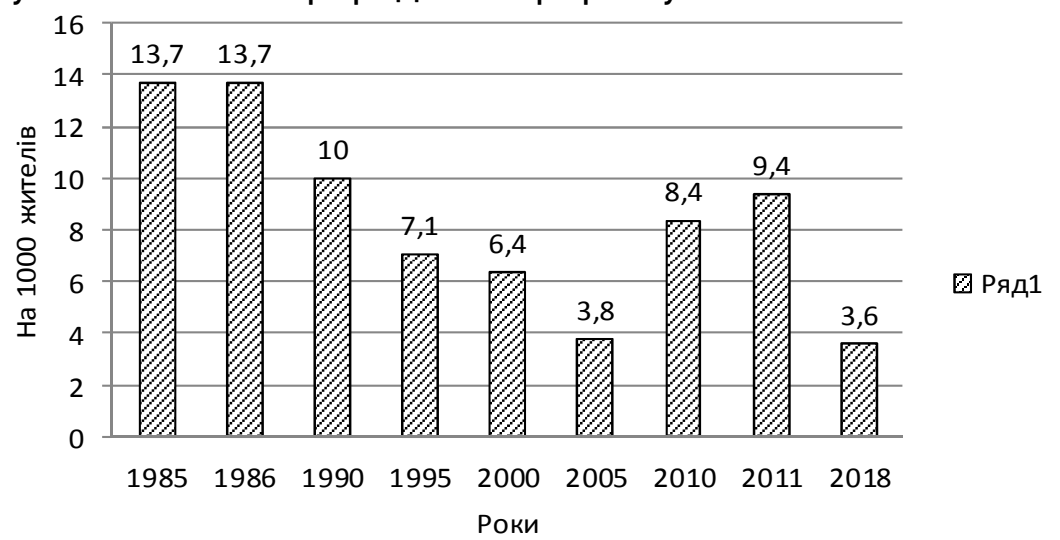

Рис. 2. Динаміка природного приросту населення Володимирецького району, на 1000 осіб населення 


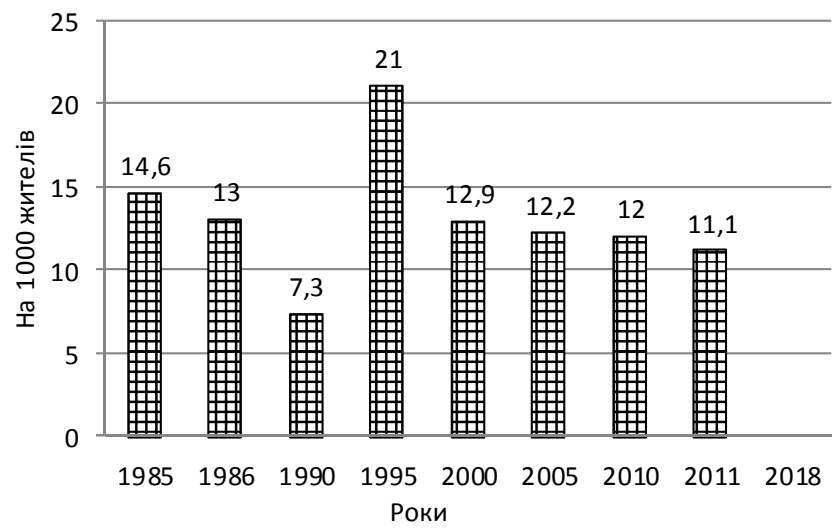

Рис. 3. Динаміка малюкової смертності Володимирецького району, на 1000 народжених живими

Аналіз рівня захворюваності населення засвідчує зростання за всіма показниками, що є негативним явищем (рис. 4).

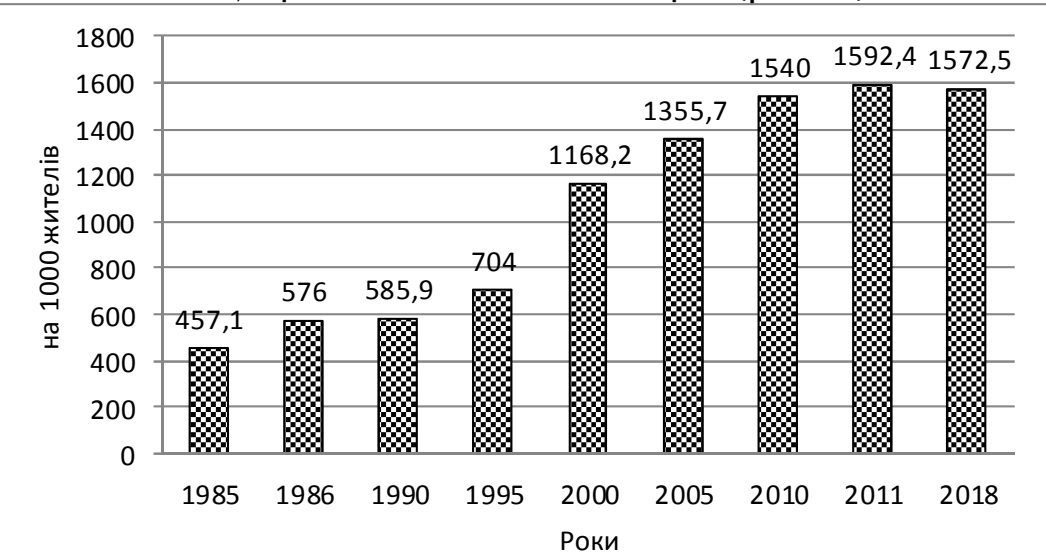

Рис. 4. Динаміка поширеності захворюваності серед населення Володимирецького району, на 1000 жителів

Динаміку новоутворень серед населення і дітей Володимирецького району наведено на рис. 5 та має тенденцію до зростання.

Динаміку захворювання на хвороби системи кровообігу (дорослі і підлітки), поширеність ендокринної патології, захворюваності на рак щитовидної залози наведено на рис. 6. Інформація наведена на рисунку та в таблицях засвідчує зростання захворювання населення.

Динаміку захворюваності населення Володимирецького району на рак шлунку та на рак кісток і сполучної тканини наведено на рис. 7, 8. 


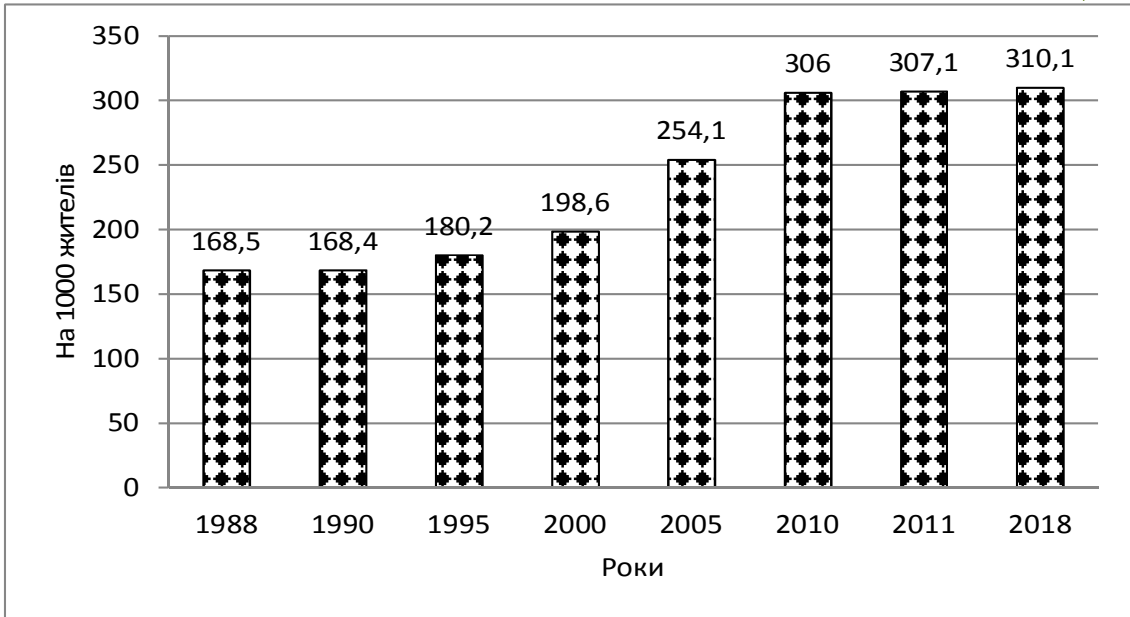

Рис. 5. Динаміка новоутворень серед населення Володимирецького району, на 1000 жителів

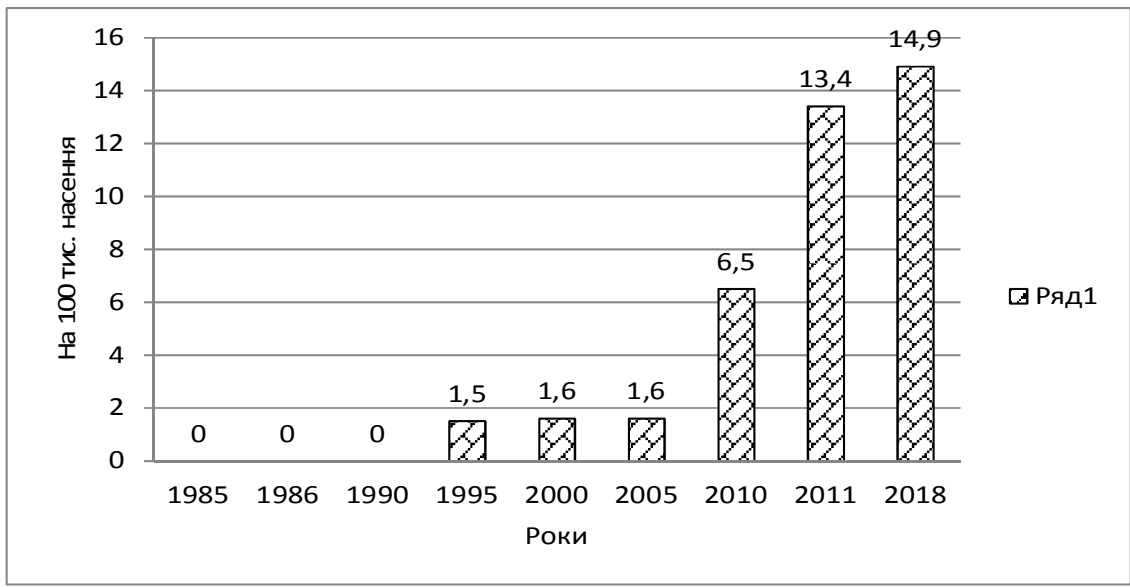

Рис. 6. Динаміка захворюваності на рак щитовидної залози населення Володимирецького району, на 100 тис. населення

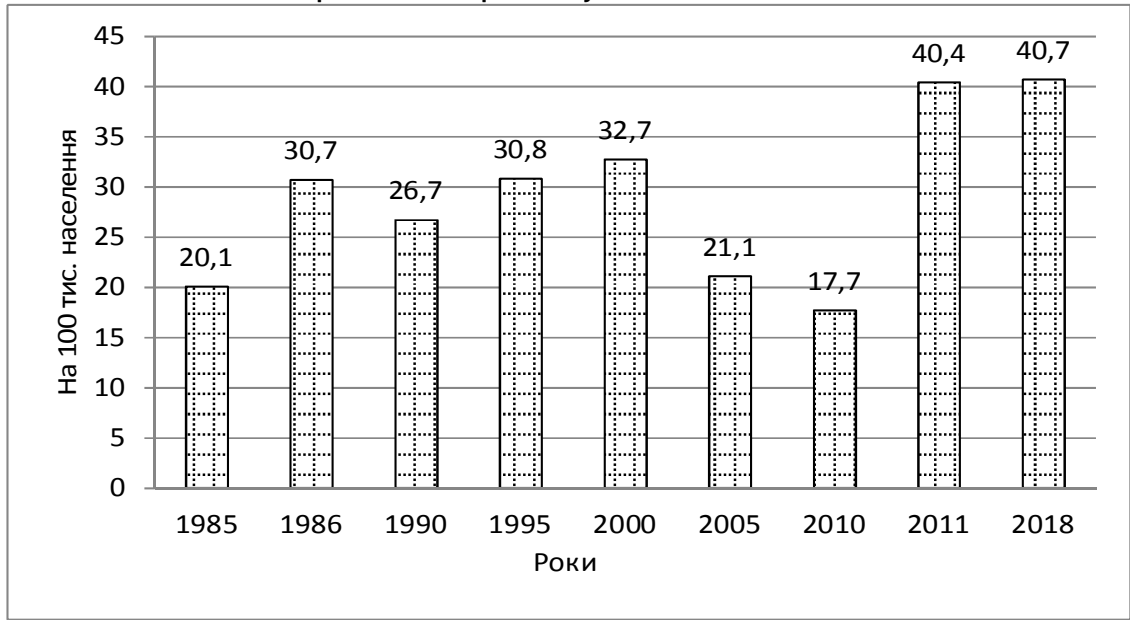

Рис. 7. Динаміка захворюваності на рак шлунку населення Володимирецького району, на 100 тис. населення 


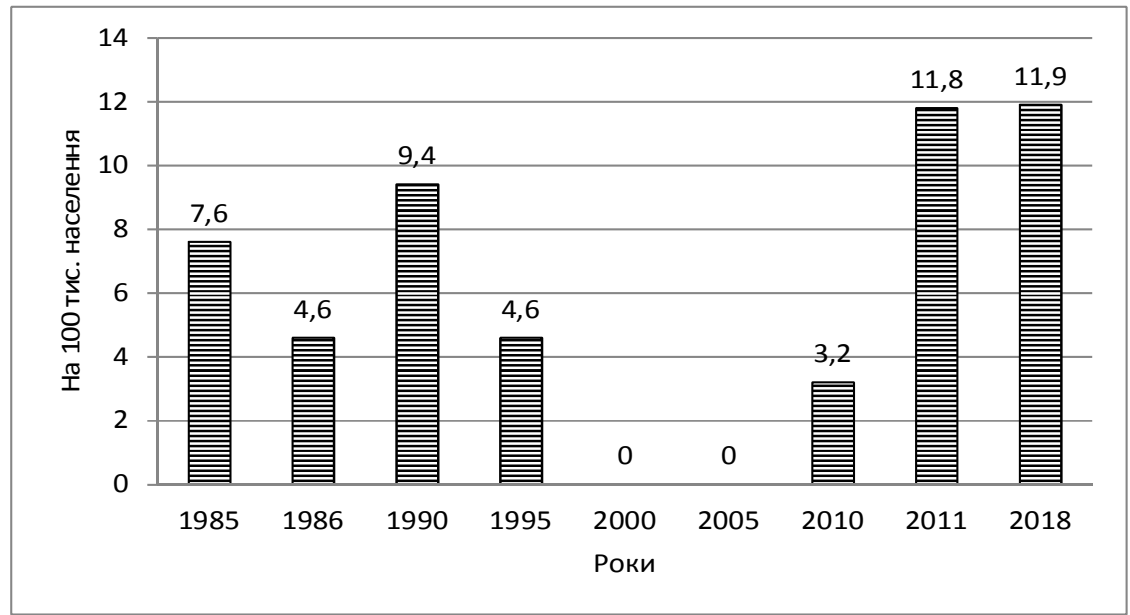

Рис. 8. Динаміка захворюваності на рак кісток і сполучної тканини населення Володимирецького району, на 100 тис. населення

Високий рівень та позитивна динаміка захворюваності населення Володимирецького району пояснюється низкою екологічних, економічних та соціальних факторів.

3 метою реформування системи охорони здоров'я, запропоновано впровадженням інноваційної моделі надання медичних послуг населенню - MIC «ЕМСІМЕД». Центральний компонентом системи $€$ програмне забезпечення, яке накопичує інформацію за певними правилами. Периферійний компонент - це медичні інформаційні системи, з якими безпосередньо працюють медичні працівники в медичних закладах. В «ЕМСіМЕД» $\epsilon$ всі інструменти для роботи медичних працівників 3 центральним компонентом eHealth M03 України (електронна медична картка пацієнта, персональні дані пацієнта).

її запровадження сприятиме вирішенню таких проблем:

- моніторинг основних показників здоров'я та з'ясування основних проблем у галузі охорони здоров'я:

- покращання доступності, своєчасності та якості медичних послуг;

- удосконалення матеріально-технічного забезпечення, використання інформаційних технологій;

- недостатності ресурсів і фінансової бази, яка стримує впровадження загальної лікарської практики на належному рівні;

- відсутності єдиного інформаційно-медичного простору лікувально-профілактичних закладів сімейної медицини тощо;

- лікувальні заклади не мають надійної системи збору, зберігання та обробки інформації.

- первинна медична ланка має вкрай низьке забезпечення 
інформацією про хворого;

- збір та обробка статистичних даних в лікувальнопрофілактичних закладах району проводиться вручну із значним впливом людського фактору, що веде до зниження об'єктивності отриманої інформації тощо.

Контроль за виконанням цих завдань неможливий без впровадження інформаційної автоматизованої системи профілактичних медичних оглядів населення. В районі актуальною $€$ проблема захворюваності на хвороби крові, новоутворення, хвороби системи кровообігу, захворюваності на рак щитовидної залози тощо. Тому наприклад, виявлення на ранніх стадіях онкологічних захворювань необхідно здійснювати шляхом наявності бази інформації про проведення онкологічних профілактичних оглядів населення та диспансерного нагляду за групами ризику та інших заходів, що в сукупності $€$ одним з елементів медичної системи. Відсутність такої системи не дає можливості здійснювати належний контроль та надання якісних послуг в районі.

Комунальне некомерційне підприємство «Володимирецька центральна районна лікарня» Володимирецької районної ради провело обгрунтування ремонту та модернізації харчового блоку й впровадження системи НАССР. Вартість таких робіт перевищила 10 млн грн. Тому заклад провів низку підготовчих заходів щодо впровадження щоденного харчування за допомогою кейтерингових послуг. ДК 021:2015 код 55520000-1 - Кейтерингові послуги (послуги з постачання готової їжі для харчування пацієнтів), «процедура відкритих торгів» (витяг).

Для здорового харчування хворих і покращання їх здоров'я запропоновано організацію харчування з включенням органічних продуктів: найперше круп, овочів, молочних виробів та напоїв 3 радіопротекторними властивостями. [22]:

Наприклад до складу продуктів харчування доцільно включити

- крупа гречана - 100 грн/кг;

- крупа вівсяна - 60 грн/кг;

- крупа гречка січка 90 грн/кг;

- крупа перловка та ячмінна - 75 грн/кг;

Овочі:

- картопля органічна - 27 грн/кг;

- морква органічна - 26 грн/кг;

- столовий буряк органічний - 22 грн/кг;

- капуста органічна - 22 грн/кг;

- цибуля органічна - 20 грн/кг; 
Борошно:

- часник органічний - 120 грн/кг;

- петрушка органічна - 85 грн/кг;

- борошно спельти (біле) - 90 грн/кг;

- борошно пшеничне вище - 80 грн/кг;

- борошно пшеничне цілозерне ( із цілого зерна) - 85 грн/кг;

- борошно гречане цілозерне - 88 грн/кг;

- борошно гречане із ядра - 120 грн/кг;

- борошно ячменю голозерного - 110 грн/кг;

- борошно вівса голозерного - 75 грн/кг;

- борошно вівса - 70 грн/кг;

- висівки пшеничні - 55 грн/кг;

Боби:

- квасоля ясік (велика біла) - 135 грн/кг;

- квасоля в асортименті (115 - 125) грн/кг;

Молочна продукція:

- молоко 1 л (2.5\%) - 44 грн;

- сметана 270 грам - 43 грн;

- кефір 1 л - 47 грн;

- сир твердий (50\%) - 350 грн/кг.

Хліб в асортименті - від 33 до 57 грн за кг.

Макарони в асортименті - 65-83 грн/кг;

Соки в асортименті - 65-180 грн/літр.

На основі цінової пропозиції на ринку органічних продуктів було складено меню та визначена вартість харчування у різних відділеннях (табл. 1).

Таблиця 1

Найменування послугіз харчування

\begin{tabular}{|c|c|c|c|c|}
\hline Найменування послуги & $\begin{array}{c}\text { Од. } \\
\text { виміру }\end{array}$ & $\begin{array}{c}\text { Кіль- } \\
\text { кість }\end{array}$ & $\begin{array}{c}\text { Ціна, } \\
\text { грн без } \\
\text { ПДВ }\end{array}$ & $\begin{array}{c}\text { Сума, } \\
\text { грн, без } \\
\text { ПДВ }\end{array}$ \\
\hline $\begin{array}{l}\text { Послуга з постачання готової їжі } \\
\text { для харчування пацієнтів } \\
\text { (гіпотрофіки) }\end{array}$ & $\begin{array}{c}\text { комп- } \\
\text { лект* }\end{array}$ & 21 & 79 & 1659 \\
\hline $\begin{array}{l}\text { Послуга з постачання готової їжі } \\
\text { (нормотрофіки) }\end{array}$ & $\begin{array}{c}\text { комп- } \\
\text { лект* }\end{array}$ & 3257 & 78 & 254046 \\
\hline $\begin{array}{c}\text { Послуга з постачання готової їжі } \\
\text { для (гіпертрофіки) }\end{array}$ & $\begin{array}{c}\text { комп- } \\
\text { лект* }\end{array}$ & 411 & 75 & 30825 \\
\hline $\begin{array}{c}\text { Послуга з постачання готової їі для } \\
\text { харчування пацієнтів (діти віком від } \\
\text { 1 до 3 років) }\end{array}$ & $\begin{array}{c}\text { комп- } \\
\text { лект* }\end{array}$ & 98 & 67 & 6566 \\
\hline
\end{tabular}




\begin{tabular}{|c|c|c|c|c|}
\hline \multicolumn{5}{|c|}{ продовження табл. 1} \\
\hline $\begin{array}{c}\text { Послуга з постачання готової їжі для } \\
\text { харчування пацієнтів (діти віком від } \\
3 \text { до } 6 \text { років) }\end{array}$ & $\begin{array}{l}\text { комп- } \\
\text { лект* }\end{array}$ & 90 & 72 & 6480 \\
\hline $\begin{array}{c}\text { Послуга з постачання готової їжі для } \\
\text { харчування пацієнтів (діти віком від } \\
7 \text { до } 10 \text { років) }\end{array}$ & $\begin{array}{c}\text { ком- } \\
\text { плект* }\end{array}$ & 116 & 80 & 9280 \\
\hline $\begin{array}{c}\text { Послуга з постачання готової їжі для } \\
\text { харчування пацієнтів (діти віком від } \\
11 \text { до } 14 \text { років) }\end{array}$ & $\begin{array}{c}\text { ком- } \\
\text { плект* }\end{array}$ & 154 & 87 & 13398 \\
\hline $\begin{array}{c}\text { Послуга з постачання готової їжі для } \\
\text { харчування пацієнтів (діти віком від } \\
15 \text { до } 18 \text { років) }\end{array}$ & $\begin{array}{c}\text { ком- } \\
\text { плект* }\end{array}$ & 159 & 89 & 14151 \\
\hline
\end{tabular}

Примітка:

*Один комплект включає сніданок, обід, вечерю 1 та вечерю 2.

** Ціна за одиницю визначається як середня величина вартості одного комплекту для харчування відповідної категорії пацієнтів (гіпотрофіки, нормотрофіки та гіпертрофіки тощо) згідно з меню.

Упровадження даного проєкту надасть можливість забезпечити якісне та безпечне харчування для різних груп хворих шляхом облаштування та впровадження кейтерінгу 3 використанням органічних продуктів; створити інформаційну базу даних на основі впровадження інформаційної системи МIC «ЕМСIMЕД»; отримувати достовірну інформацію про стан здоров'я населення району та надані послуги; покращити рівень і якість медичного обслуговування жителів району; приймати ефективні управлінські рішення, що забезпечить зниження рівня захворюваності, інвалідності, смертності та допоможе подолати несприятливі демографічні тенденції. Водночас збільшення попиту на органічну продукцію сприятиме розвитку в регіоні соціально відповідального бізнесу, збереженню та поступовому відновленню родючості ґрунтів.

1. Формування господарських систем на базі природно-ресурсних комплексів / за заг. ред. д.е.н., проф. В.А. Голяна. К. : Державна установа «Інститут економіки природокористування та сталого розвитку Національної академії наук України», 2016. 259 с. 2. Економічні аспекти управління природними ресурсами та забезпечення сталого розвитку в умовах децентралізації влади в Україні / за наук. ред. акад. НААН України, д.е.н., проф. М.А. Хвесика, д.г.-м.н., проф. С. О. Лизуна ; Державна установа «нститут економіки природокористування 244 та сталого розвитку Національної академії наук України». К. : ДУ ІЕПСР НАН України, 2015. 72 с. 3. Павловський В. А. та ін. Віддалені наслідки Чорнобильської катастрофи. Вісник Житомирського педуніверситету. 2003. № 11. С. 249-252. 4. Moiseenko R. A., 
Dudina E. A., Goyda N. G. Analysis of incidence and prevalence of diseases among children in Ukraine for the 2011-2015 period. Sovremennaya pediatriya. 2017. doi:10.15574/SP.2017.82.17. 5. Dudina 0. 0., Tereshchenko A. V. Achievements, problems and solutions in the protection of maternal and child health. In: Rezul'taty dijal'nosti galuzi ohorony zdorov'ja. Results of the health sector. Kyiv, 2012. 35-37 pp.

6. Ціборовський О.М. Динаміка демографічної ситуації у зв'язку з соціальноекономічними умовами в Україні. К., 2010. 99 с. 7. Чепелевська Л. А. Медикосоціальні особливості смертності населення України. Україна. Здоров'я нації. 2010. № 4 (16). С. 37-42. 8. Щорічна доповідь про стан здоров'я населення, санітарноепідемічну ситуацію та результати діяльності системи охорони здоров'я України. 2015 рік / за ред. О. Квіташвілі ; МОЗ України, ДУ «УІСД МОЗ України». Київ : МВЦ «Медінформ», 2016. 461 с. 9. Ященко Ю. Б., Кондратюк Н. Ю. Динаміка захворюваності та смертності внаслідок хвороб системи кровообігу в Україні (регіональний аспект). Україна. Здоров'я нації. 2013. № 1 (25). С. 20-27. 10. Барановський В.А. Екологічна географія і екологічна картографія / редкол.: С. І. Дорогунцов (відп. ред.) та ін. ; НАН України. Рада по вивч. продукт. сил України. К. : Фітосоціоцентр, 2001. 250 с. 11. Гуцуляк В. М. Медична географія (екологічний аспект). Чернівці, 1997. 72 с. 12. Хлебович И. А., Ротанова И.Н. Медикоекологическое районирование по факторам риска. География и природные ресурсы. 2000. № 4. С. 135-142. 13. Кольцова Н.І., Дерик О. 3. (ред.) Соціальна медицина і організація охорони здоров'я. Івано-Франківськ, 2007. 304 с. 14. Корнацький В. М., Клименко В.І. Хвороби системи кровообігу і психічне здоров'я. Здоров'я. Київ, 2009. 176 с. 15. Корнус А. О., Корнус О.Г., Шищук В. Д. Роль медико-екологічних досліджень у геоекологічному аналізі регіону. Наук. вісн. Чернівец. ун-ту : зб. наук. праць. 2012. Вип. 614-615. С. 67-70. 16. Кушнірук Ю. С., Волкова Л. А. Медикогеографічні засади дослідження території (на прикладі оцінки медикоекологічного ризику території Рівненської області). Рівне: НУВГП, 2019. 208 с. 17. Державна служба статистики України. Захворюваність населення України у 2017:

URL: http://www.ukrstat.gov.ua/druk/publicat/kat_u/2018/zb/06/zb_zoz_17.pdf. (дата звернення: 30.09.2020). 18. Медико-демографічні аспекти Чорнобильської катастрофи / Толстанов 0. К. та ін. URL: https://eprints.zu.edu.ua. (дата звернення: 30.09.2020). 19. Показники здоров'я та надання медичної допомоги потерпілим внаслідок аварії на Чорнобильській AEC за 2005 рік : статистично-аналітичний довідник. К. : Видавництво НДВП «Техмедекол», 2006. 197 с. 20. Медичні аспекти впливу малих доз радіації на організм дітей : зб. наук. праць / за редакцією Т.К. Навохотчого, .М. Пономаренко, В.Й.Шатило. Житомир. 1996. 114 с. 21.Дячук Д.Д.. Ященко Ю.Б., Лисенко Ю. Поширеність хвороб системи кровообігу серед дорослого населення, якому надається медична допомога у ДНУ «НПЦ ПКМ» ДУС. Вісник проблем біології і медицини. 2015. Вип. 2. Том 1 (118). C. 290-294. 22. Інтернет магазин органічних та еко продуктів EcoClub. URL: https://ecoclub.ua (дата звернення: 30.09.2020).

\section{REFERENCES:}

1. Formuvannia hospodarskykh system na bazi pryrodno-resursnykh kompleksiv / za zah. red. d.e.n., prof. V. A. Holiana. K. : Derzhavna ustanova «Instytut ekonomiky pryrodokorystuvannia ta staloho rozvytku Natsionalnoi akademii nauk Ukrainy», 2016. 259 s. 2. Ekonomichni aspekty upravlinnia pryrodnymy resursamy ta zabezpechennia staloho rozvytku $v$ umovakh detsentralizatsii vlady $v$ Ukraini / za nauk. red. akad. 
NAAN Ukrainy, d.e.n., prof. M. A. Khvesyka, d.h.-m.n., prof. S. O. Lyzuna ; Derzhavna ustanova «Instytut ekonomiky pryrodokorystuvannia 244 ta staloho rozvytku Natsionalnoi akademii nauk Ukrainy». K. : DU IEPSR NAN Ukrainy, 2015. 72 s. 3. Pavlovskyi V. A. ta in. Viddaleni naslidky Chornobylskoi katastrofy. Visnyk Zhytomyrskoho peduniversytetu. 2003. № 11. S. 249-252. 4. Moiseenko R. A., Dudina E. A., Goyda N. G. Analysis of incidence and prevalence of diseases among children in Ukraine for the 2011-2015 period. Sovremennaya pediatriya. 2017. doi:10.15574/SP.2017.82.17. 5. Dudina 0. 0., Tereshchenko A. V. Achievements, problems and solutions in the protection of maternal and child health. In: Rezultaty dijalnosti galuzi ohorony zdorovja. Results of the health sector. Kyiv, 2012. 35-37 pp. 6. Tsiborovskyi 0. M. Dynamika demohrafichnoi sytuatsii u zviazku z sotsialnoekonomichnymy umovamy v Ukraini. K., 2010. 99 s. 7. Chepelevska L. A. Medykosotsialni osoblyvosti smertnosti naselennia Ukrainy. Ukraina. Zdorovia natsii. 2010. № 4 (16). S. 37-42. 8. Shchorichna dopovid pro stan zdorovia naselennia, sanitarnoepidemichnu sytuatsiiu ta rezultaty diialnosti systemy okhorony zdorovia Ukrainy. 2015 rik / za red. O. Kvitashvili ; MOZ Ukrainy, DU «UISD MOZ Ukrainy». Kyiv : MVTs «Medinform», 2016. 461 s. 9. Yashchenko Yu. B., Kondratiuk N. Yu. Dynamika zakhvoriuvanosti ta smertnosti vnaslidok khvorob systemy krovoobihu v Ukraini (rehionalnyi aspekt). Ukraina. Zdorovia natsii. 2013. № 1 (25). S. 20-27. 10. Baranovskyi V. A. Ekolohichna heohrafiia i ekolohichna kartohrafiia / redkol.: S. I. Dorohuntsov (vidp. red.) ta in. ; NAN Ukrainy. Rada po vyvch. produkt. syl Ukrainy. K. : Fitosotsiotsentr, 2001. 250 s. 11. Hutsuliak V. M. Medychna heohrafiia (ekolohichnyi aspekt). Chernivtsi, 1997. 72 s. 12. Hlebovich I. A., Rotanova I. N. Mediko-ekologicheskoe rayonirovanie po faktoram riska. Geografiya i prirodnyie resursyi. 2000. № 4. S. 135-142. 13. Koltsova N. I., Deryk 0. Z. (red.) Sotsialna medytsyna i orhanizatsiia okhorony zdorovia. IvanoFrankivsk, 2007. 304 s. 14. Kornatskyi V. M., Klymenko V. I. Khvoroby systemy krovoobihu i psykhichne zdorovia. Zdorovia. Kyiv, 2009. 176 s. 15. Kornus A. O., Kornus O. H., Shyshchuk V. D. Rol medyko-ekolohichnykh doslidzhen u heoekolohichnomu analizi rehionu. Nauk. visn. Chernivets. un-tu : zb. nauk. prats. 2012. Vyp. 614-615. S. 67-70. 16. Kushniruk Yu. S., Volkova L. A. Medyko-heohrafichni zasady doslidzhennia terytorii (na prykladi otsinky medyko-ekolohichnoho ryzyku terytorii Rivnenskoi oblasti). Rivne: NUVHP, 2019. 208 s. 17. Derzhavna sluzhba statystyky Ukrainy. Zakhvoriuvanist naselennia Ukrainy u 2017: URL: http://www.ukrstat.gov.ua/druk/publicat/kat_u/2018/zb/06/zb_zoz_17.pdf. (data zvernennia: 30.09.2020). 18. Medyko-demohrafichni aspekty Chornobylskoi katastrofy / Tolstanov 0. K. ta in. URL: https://eprints.zu.edu.ua. (data zvernennia: 30.09.2020). 19. Pokaznyky zdorovia ta nadannia medychnoi dopomohy poterpilym vnaslidok avarii na Chornobylskii AES za 2005 rik : statystychno-analitychnyi dovidnyk. K. : Vydavnytstvo NDVP «Tekhmedekol», 2006. 197 s. 20. Medychni aspekty vplyvu malykh doz radiatsii na orhanizm ditei : zb. nauk. prats / za redaktsiieiu T. K. Navokhotchoho, V. M. Ponomarenko, V. Y. Shatylo. Zhytomyr. 1996. 114 s. 21. Diachuk D. D.. Yashchenko Yu. B., Lysenko I. Yu. Poshyrenist khvorob systemy krovoobihu sered dorosloho naselennia, yakomu nadaietsia medychna dopomoha u DNU «NPTs PKM» DUS. Visnyk problem biolohii i medytsyny. 2015. Vyp. 2. Tom 1 (118). S. 290-294. 22. Internet mahazyn orhanichnykh ta eko produktiv EcoClub. URL: https://ecoclub.ua (data zvernennia: 30.09.2020). 
Skrypchuk P. M. [1; ORCID ID: 0000-0002-2835-4711], Doctor of Economics, Professor of the Department of Management,

Shpak H. M. ${ }^{[2 ;}$ ORCID ID: 0000-0002-8588-441X], Candidate of Economics (Ph.D.),

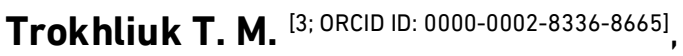
Candidate of Economics (Ph.D.),

Karaimchuk I. V. ${ }^{[4]}$, Chief Physician

${ }^{1}$ National University of Water and Environmental Engineering, Rivne

${ }^{2}$ VSP «Rivne Technical Vocational College» NUWEE, Rivne

${ }^{3} \mathrm{VSP}$ «Berezne Forestry Technical College» NUWEE, Berezne

${ }^{4}$ Volodymyrets Central District Hospital, Volodymyrets

\section{INFORMATION-ANALYTICAL AND SOCIAL COMPONENTS OF SECURITY OF TERRITORIAL AND ECONOMIC SYSTEMS FUNCTIONING}

It might be possible to ensure safe conditions and high living standards for the population only provided that the balance between economic development and the ability to reproduce natural resources is reached. This is especially difficult to achieve in the areas that are economically depressed and environmentally polluted. Analysis of the medical and demographic situation in the Volodymyrets district of Rivne region showed that the general incidence rate has increased 3.5 times over the past 30 years. The problem of blood diseases, neoplasms, diseases of circulatory system, thyroid cancer cases, etc is vital in this region. This is primary a result of the difficult radio-ecological situation in the area, which is worsened by a number of negative economic and social factors. In order to improve the efficiency of providing medical services to the people, it is suggested to introduce an innovative model - MIS «EMSIMED». It involves using information technology for collecting, storing and processing of medical data and key indicators of public health, monitoring the regular medical examination of the population. Besides, it has been proposed to include organic food having radio-protective properties into the daily diet of patients. Organic meals might be arranged with the help of catering service (supply of ready-made meals for patients.) The cost of organic set (4 meals a day) is ranging from 79 to 89 hryvnias per day. The implementation of the given measures will ensure a reduction in morbidity, disability and mortality of the population and will help to overcome unfavorable demographic trends. At the same time, growing demand for organic food products on condition of government procurement will contribute to the development of socially responsible business in the region, preservation and gradual restoration of soil fertility, improving the environmental situation in the area on the whole. 
Keywords: the level of morbidity of the population; information system MIS «EMSIMED»; healthy food; organic products; catering services.

Скрипчук П. М. [1; ORCID ID: 0000-0002-2835-4711], д.э.н., профессор кафедры менеджмента,

Шпак Г. Н. [2; ORCID ID: 0000-0002-8588-441X], К.э.H.

Трохлюк T. H. ${ }^{[3 ;}$ ORCID ID: 0000-0002-8336-8665]

К.э.Н.

Караимчук И. В. ${ }^{[4]}$, главный врач

\footnotetext{
${ }^{1}$ Национальный университет водного хозяйства и природопользования, г. Ровно, ${ }^{2} В С П$ «Ровенский технический профессиональный колледж» НУВХП, г. Ровно, ${ }^{3} О С П$ «Березнивский лесотехнический профессиональный колледж» НУВХП, г. Березно

${ }^{4} К Н П$ «Владимирецкая центральная районная больница», пгт Владимирец
}

\section{ИНФОРМАЦИОННО-АНАЛИТИЧЕСКАЯ И СОЦИАЛЬНАЯ СОСТАВЛЯЮЩИЕ БЕЗОПАСНОСТИ ФУНКЦИОНИРОВАНИЯ ТЕРРИТОРИАЛЬНО-ХОЗЯЙСТВЕННЫХ СИСТЕМ}

Обеспечить безопасные условия и высокое качество жизни населения можно только при установке баланса между экономическим развитием и способностью воспроизводства природных ресурсов. Особенно сложно это сделать на территориях, которые являются экономически депрессивными и экологически загрязненными. Анализ медико-демографической ситуации в Владимирецком районе Ровенской области показал, что уровень заболеваемости населения по сравнению за последние 30 лет вырос в 3,5 раза. В районе актуальна проблема заболеваемости новообразованиями, болезнями системы кровообращения, заболеваемости раком щитовидной железы и др. В первую очередь это объясняется сложной радиоэкологической ситуацией в регионе, осложняется рядом негативных экономических и социальных факторов. С целью повышения эффективности предоставления медицинских услуг населению, предложено ввести инновационную модель МИС «ЭМСИМЕД». Она предусматривает использование информационных технологий для сбора, хранения, обработки медицинских данных и основных показателей здоровья населения, контроля проведения профилактических осмотров. Кроме того, предложено включить органические продукты с радиопротекторными свойствам в ежедневный рацион больных. Организовать органическое питание можно с помощью кейтеринговых 
услуг (поставка готовой пищи для питания пациентов). Стоимость органического комплекта (4-разовое питание) составляет от 79 до 89 гривен в день. Реализация этих мероприятий обеспечит со временем снижение уровня заболеваемости, инвалидности, смертности населения и поможет преодолеть неблагоприятные демографические тенденции. В то же время, увеличение спроса на органическую продукцию через госзаказ, будет способствовать развитию в регионе социально ответственного бизнеса, сохранению и постепенному восстановлению плодородия почв, улучшению экологической ситуации в регионе в целом. Ключевые слова: уровень заболеваемости населения; информационной системы МИС «ЭМСИМЕД»; органические продукты.

Стаття надійшла до редакції 02.10.2020 p. 